\title{
Book Review "Don't Know Much About Caddo Archeology, Don't Know Much ...."
}

Timothy K. Perttula

Heritage Research Center, Stephen F. Austin State University

Follow this and additional works at: https://scholarworks.sfasu.edu/ita

Part of the American Material Culture Commons, Archaeological Anthropology Commons, Environmental Studies Commons, Other American Studies Commons, Other Arts and Humanities Commons, Other History of Art, Architecture, and Archaeology Commons, and the United States History Commons

Tell us how this article helped you.

This Article is brought to you for free and open access by the Center for Regional Heritage Research at SFA ScholarWorks. It has been accepted for inclusion in Index of Texas Archaeology: Open Access Gray Literature from the Lone Star State by an authorized editor of SFA ScholarWorks. For more information, please contact cdsscholarworks@sfasu.edu. 
Book Review "Don't Know Much About Caddo Archeology, Don't Know Much .... "

Creative Commons License

(c) (1) (9)

This work is licensed under a Creative Commons Attribution-NonCommercial 4.0 International License 


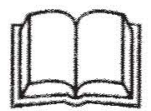

\section{Book Review}

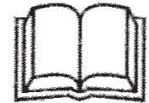

\section{"Don't Know Much About Caddo Archeology, Don't Know Much .... "}

In an otherwise interesting and recently published book by Judith Nies (1996) entitled Native American History, there is an extremely wide-of-the-mark discussion of the Spiro site which I would like to share with the readers of Caddoan Archeology. The inaccuracy of the presentation conveys all too well, unfortunately, how little is still known about Caddoan archeology, and about the Caddo peoples, among the general public and the general reader.

According to Nies (1996:37), the Spiro site "on the Red River" was settled in A.D. 600. How the site ended up on the Red River, instead of in eastern Oklahoma along the Arkansas River, is a mystery! of course, if the Spiro site was on the Red River, that would clear up a current controversy or two, wouldn't it?

Nies (1996:37) goes on to state that "among the still-existing ruins [at Spiro] are a two-mile-long, 200-foot-high ridge; a central ceremonial structure almost 600 feet long and 30 feet high (called Battle Place by recent archaeologists) with two raised platforms; as well as eight peripheral mounds". Now we find that Spiro actually contains the large Battle site earthen mound, on Chicaninna Prairie in south- western Arkansas the last time I checked, as well as a massive ridge of astounding proportions. This ridge - of natural construction - in actuality is the pine and oak-covered Boyd Hill not far from the Battle site

The only other mention of the Caddo in Nies' book concerns the devastating effects of guns, epidemics, and slavery introduced by the Europeans following the De Soto entrada (Nies 1996:76). She suggests that the Caddo culture was wiped out, preserved only in "oral traditions, in recovered artwork, and in place names [at least those that are used accurately, I guess] and archaeological remains that insist on telling their story" [brackets added]. Anyone who has been to the Caddo Tribe's center in Binger, Oklahoma, talked and danced with Caddo peoples at a Caddo Conference, or read Cecile Carter's (1994) wonderful book on the Caddo, for instance, can attest to the utter fallacy of Nies" suggestion. Come visit the Caddo people in Oklahoma (yes, Judith, that is Oklahoma, not Arkansas!), and learn some things about the strengths and traditions preserved in Caddo culture

Timothy K. Pertula 


\section{REFERENCES CITED}

Carter, Cecile Elkins

1995 Caddo Indians: Where We Came

From. University of Oklahoma

Press, Norman.
Nies, Judith

1996 Native American History: A Chronology of a Culture's Vast Achievements and Their Links to World Events. Ballantine Books, New York. 